\title{
The interactions between literature and philosophy: a view from Russia
}

\section{Guest editor's introduction}

\author{
Elena A. Takho-Godi ${ }^{1,2}$ (B)
}

Accepted: 8 December 2020 / Published online: 4 January 2021

(c) The Author(s), under exclusive licence to Springer Nature B.V. part of Springer Nature 2021

Scholars are increasingly aware today of what may be called a "conflicting interference" between the methods of philology and philosophy, the pendulum swinging between philosophy waxing the philological and philology waxing the philosophical. In the twentieth century, it became common to recognize traces of literary thinking in all spheres of human activity. In the 1930s, the American philosopher and intellectual historian Arthur Oncken Lovejoy, in his book The Great Chain of Being: A Study of the History of an Idea (1936), spoke of the need to include literary history in the history of ideas. Present-day exponents of intellectual history emphasize the similarity of literature and history as different types of writing varying only in their purpose, genre, and nature of discourse. In his book Figural Realism: Studies in the Mimesis Effect (1999), the head of the literary turn in historical scholarship Hayden White argued that literary techniques can be applied to historical texts to detect tropes and allegories in them. Jean Starobinski, a well-known Swiss literary critic who studied at one time with the philosopher Maurice Merleau-Ponty, stressed in an interview that "there are points of intersection between 'ideas' and 'images',"so that a modern philologist should "be able to become something of a philosopher-historian who does not neglect to refer to the documents of the past, and not just to systems and ideas" (Starobinski 2014, p. 185). At the same time, philosophy is in dialog with the study of literature (Rudrum 2006; Rudrum et al. 2019), and philosophy of literature is currently a thriving and increasingly influential branch of aesthetics (Lamarque 2009; Schroeder 2010).

The late twentieth-century debates about the relationship between philosophical and literary issues, between what is usually called metaphysical, epistemological,

Elena A. Takho-Godi

takho-godi.elena@yandex.ru

1 Department of the History of Russian Literature, M.V. Lomonosov Moscow State University, Leninskie gory, 1st academic building, Moscow, Russia 119991

2 Department of Russian Literature of the Late Nineteenth-Early Twentieth Centuries, A.M. Gorky Institute of World Literature of the Russian Academy of Sciences, 25a Povarskaya St., Moscow, Russia 121069 
or ontological questions, on the one hand, and questions of artistic presentation, form and content, as well as aesthetic value, on the other, were greatly stimulated by Martin Heidegger's later works, in particular by his concept of poetic thinking as distinct from logical-rational thought (Halliburton 1981; Stellardi 2004). Heidegger, along with Maurice Blanchot, who was both a theoretical philosopher and a writer, became instrumental for Jacques Derrida's approach to philosophy as a specific literary genre that should be placed close to poetry and explored from the point of view of its artistic structure (Clark 2008). For poststructuralism and deconstructivism in general the metaphorical nature of language itself became the theoretical basis for viewing philosophical and literary problems as mutually related. However, while reducing the emphasis on logical-rational thinking in favor of poetic thinking, the proponents of these movements also rejected philosophical conceptual universalism. The very fact of this rejection is probably the most obvious difference between the Western European intellectual tradition and its Russian counterpart in their approaches to the interaction between literature and philosophy. ${ }^{1}$ Not without reason in the book New Directions in Philosophy and Literature Claire Colebrook states: "One cannot avoid the universal strivings of thought, but any attempt to articulate universals requires some specific and singular inscription. Philosophy is inevitably caught up with the force of literature" (Rudrum et al. 2019, p. 14).

Unlike the Western European tradition, Russian culture never developed a firm boundary between these two disciplines. Russian literature of the nineteenth century was a synthetic form of national self-consciousness and fulfilled the role of a national Russian philosophy:

Russian classical literature, however, is all powerful because it fulfilled the role of national Russian philosophy in the nineteenth century, not as an 'ersatz' or 'surrogate' that might not have existed if its own philosophy had developed on Russian soil, but as a qualitatively new phenomenon that has never been seen before in the history of literature, philosophy, or religion. The fact is that on the Russian "native soil" of the nineteenth century, the intellectual comprehension of the world could not develop in the form of philosophy, not only because of the lack of political freedom, strict censorship, etc., but also because of the peculiarities of Russian life, which for its adequate reflection required not a philosophical system, but a novel. (Gachev 1981, p. 12) ${ }^{2}$

The Russian Romantics absorbed the latest Western philosophical thought, primarily the ideas of Schelling and Hegel. The original Russian philosophy of the liubomudry ("lovers of wisdom") and the Slavophiles arose precisely from an attempt to generalize this experience. It is no accident that the first Russian philosophical novel, Russkie nochi (Russian nights, publ. 1844), by Vladimir Odoyevsky

\footnotetext{
1 The problem of the interaction between literature and philosophy is approached from different positions in such works as (Bourbon 2004; Clowes 2004; Feger 2012).

2 Russian religious thinkers, such as Vladimir Ern and Aleksei Losev (see Losev's article "Russian philosophy" (1919) in: Takho-Godi 2014, pp. 191-280) wrote about this in the beginning of the twentieth century.
} 
was written at that time. Odoyevsky confronts three philosophical views of the world: the sensualist Étienne Bonnot de Condillac, Schelling's identity philosophy, and mystical thought (largely going back to Louis Saint-Martin), but what the thinkers expressed by theoretical constructions, the writer conveyed through the action of his characters. But at the same time this novel, created in the early 1830 s, provided a full expression of Russian romantic historiosophy. Anticipating the disputes between Westerners and Slavophiles, Odoyevsky spoke about the relationship between the West and Russia, and almost 100 years before Oswald Spengler, talked about the decline of Europe.

However, despite an abiding interest in Western philosophy, Russian philosophy of the second half of the nineteenth century remained uninterested in the Western European manner of philosophizing by building philosophical systems. It remained this way until the 1870-1880s, until the Vladimir Solovyov appeared on the philosophical scene. For most Russian intellectuals of the nineteenth century, it had been literature that was the genuine method of philosophizing. Russian classical literature-from Alexandr Pushkin, Mikhail Lermontov, and Fyodor Tyutchev to Leo Tolstoy and Fyodor Dostoevsky - appeared to the reader as a figurative-artistic form of the philosophical exploration of reality.

By the early twentieth century, amid a religious-philosophical Renaissance, the vector of influence changed: religious and philosophical thought began to dominate over the poetics of the literary text. And yet the works of such prominent philosophers of the period as Nikolay Berdyaev, Sergey Bulgakov, Vasily Rozanov, and Pavel Florensky, doubtless remained, as it were, "literature-centric." The change of ideological paradigms that became dominant after 1917 affected the interaction between literature and philosophy but did not abolish it all together: the allegedly "abstract" ideas of philosophy gave way to sociological analysis and attention to concrete social phenomena. Moreover, literary genres have changed, too, both in social thought and in the literary process-from Symbolist "mystery plays" to the Expressionist style of dystopias (e.g., Evgeny Zamyatin and Andrey Platonov), which gave rise to the creative works of writer-philosophers of the 1920s-1930 s (e.g., Aleksei Losev and Valerian Muravyov). No wonder Mikhail Bakhtin scholars stress that for him "to be a philosopher ... it was necessary to be a literary critic and linguist" and to be a literary historian "it was impossible to avoid philosophizing" (Ryklin 1992, p. 87).

Attention to the question of the relationship between literature and philosophy in Russian literary studies was revived in the 1970s, not only due to the interest in Mikhail Bakhtin's work, but also largely, first, thanks to the studies of the legacy of the liubomudry-Vladimir Odoyevsky, Dmitry Venevitinov, Stepan Shevyrev (Mann 1969; Maymin 1976), and then thanks to the studies of the legacy of the Slavophiles, theorists of "native soil movement," pan-Slavists, who combined in one person writers, poets, literary critics, and thinkers: Aleksey Khomyakov, Ivan Kireevsky, Konstantin Aksakov, Ivan Aksakov, Apollon Grigoryev, Fyodor Tyutchev, Fyodor Dostoevsky, Nikolay Strakhov, Konstantin Leontyev, and others. However, a true paradigm shift in approaching this question took place in the 2000s, when previously banned religious and philosophical texts, both from the pre-revolutionary period and the era of mass Russian emigration between 1917 and 1922, fully 
returned to cultural and scholarly circulation (Semenova 2004). As a result, over the last fifteen years such books as the anthology about poetry as a genre of Russian philosophy (Sizemskaia 2007) and the materials of the round table on problems of mutual relations between philosophy and literature (Filosofiya i literatura: problemy vzaimnykh otnosheniy 2009) have appeared. Natalia Azarova's monograph considers the phenomenon of parallel development, interaction, mutual influence and convergence of the language of Russian philosophy and poetry of the twentieth - and twenty-first centuries (Azarova 2010). Sergei Kibalnik approaches Pushkin as a deep artistic philosopher and explores the main features of Pushkin's artistic thinking and his original aesthetic position (Kibalnik 2019). Based on Russian poetry of the late eighteenth - twentieth centuries, Alla Radionova develops the concept of "lyricphilosophical metatext," and studies poetic techniques and structures that form it (Radionova 2019). Nowadays there are many Russian professional philosophers working on the topic in question: Vladimir K. Kantor, Aleksandr L. Dobrokhotov, Alexei A. Kara-Murza, Irina N. Sizemskaya, Sergei A. Nikolsky, Vladimir Porus, Olga Zhukova, etc. There are also several special issues of the journal Russian Studies in Philosophy devoted to Russian literati (such as Tolstoy, Dostoevsky, Chekhov, Turgenev, Pushkin, Lermontov, Platonov, etc.), which address relevant topics (see Grevtsova 2011; Bykova 2011; Nikolsky 2016; Sizemskaya 2018; Kantor 2019; Dobrokhotov 2019; Zhukova 2019).

In 2017 the A.M. Gorky Institute of World literature at the Russian Academy of Sciences, with financial support from the Russian Science Foundation, ${ }^{3}$ created a research team to conduct an interdisciplinary study of the interactions between Russian literature and philosophy. The group traced the history of such interactions in the nineteenth and twentieth centuries, focusing on texts by the most prominent Russian writers, literary critics, and philosophers. In the course of this research new archive materials were introduced into scholarly use (e.g., from the archives of Vladimir Solovyov, Aleksei Losev, Aleksandr Gorsky, Valerian Muravyov, and others).

Exploration of the effects of the philosophical and cultural-historical context on a literary text, as well as the interactions between philosophical, aesthetic, and literary studies and between religious and philosophical images and motifs, made it possible for scholars to reflect on the dynamics and the main trends in the mutual connections between literature and philosophy and to establish their chronological boundaries and the mechanisms for generating philosophically rich literary symbols and mythologemes. Examination of such topics of Russian literary works as the aesthetics of Nature, views on space and time, utopian ideas, philosophy of history and artistic anthropology led to the conclusion about mutual interdependence of the anthropological and historiosophical models in Russian culture as a whole. This work also showed that the main features of the image of the future, such as orientation towards values, alternative character, universality, cosmic sense of existence, immortalism, unity of the individual and the community, and transformation of technical into organic progress were common to the philosophers and the artists who

$\overline{3}$ RSF, Projects No. 17-18-01432 and No. 17-18-01432-П. 
belonged to the Cosmism of the late nineteenth - early twentieth centuries. Analysis of the philosophical and aesthetic foundations of literary criticism, the questions of reconstructing the author's theory of creativity, ontology and teleology of artistic rhythm, implicit philosophy, and access to the author's philosophical and theological views through their texts became the basis for developing research strategies and methodological approaches, including the subject-subject method of reading literary texts. $^{4}$

The project participants have initiated a number of international round tables and conferences, the latest of which, in the fall of 2020, coincided with the 220th anniversary of the birth of Evgeny Boratynsky and was dedicated to the phenomenon of "the poetry of thought" from Romanticism to Modernism. The book series "Russian Literature and Philosophy: Ways of Interaction" was created and included collected works devoted to theoretical questions (Takho-Godi 2018a) or to individuals personalities-Vladimir Odoyevsky (Takho-Godi 2019) and Vladimir Solovyov (TakhoGodi 2018b). In her monograph, Tatiana Kasatkina demonstrates what the philosophy of Dostoevsky's works is, why it exists in his texts as internal and implicit, how exactly it exists there and by what means it is revealed to the reader (Kasatkina 2019). In her book, Anastasia Gacheva focuses on the study of the central existential themes of Russian thought (Vladimir Solovyov, Nikolay Fedorov, Sergey Bulgakov) and literature related: death and immortality, man and Nature, memory and resurrection, the meaning of history and the meaning of creativity, the philosophy of love, etc. (Gacheva 2019). The work of the group also resulted in special issues of various journals, such as Russian Studies in Philosophy (Takho-Godi 2018c) and Transcultural Studies, 2019, vol. 15.

The present issue includes the essays by all the team members collaborating on this project, as well as of a number of other Russian scholars exploring similar themes. The purpose of this collection is to present to a Western audience various approaches used by Russian literary scholars in studying the manifold relationship between Russian literature and philosophy based on material spanning the period from the 1840 s to the 1930 s.

Andrey Dmitriyev introduces a previously unknown work by Aleksey Khomyakov Slavianskoye $i$ pravoslavnoye naseleniye Avstrii ("The Slavic and Orthodox Christian Population of Austria"), published anonymously in 1845 in a collaborative volume The Historical and Statistical Report on Russia, edited by Dmitry Valuyev,

\footnotetext{
4 "Subject-subject method is a method for exploration of reality, where the perceiving person comes into an equal interaction with the perceived (not imposing on him a series of actions, at the same time remaining out of the immediate contact, as it is usual for the subject-object method of perception). The subject-subject method aims to establish not only the external characteristics and some objective processes in the perceived, but its inner life and consciousness. The main instrument for this method is the very personality of the perceiver, who voluntarily diminishes herself in front of the perceived in order not to distort or mask the knowledge thus passed. As a result of such an interaction on each new stage of the hermeneutic circle not only the vision of correlation between the common and particular in the perceived, but also the personality of the researcher himself is being changed. On each new stage of the interaction between the perceived and perceiving personality more new data and new levels of generalization become available - thanks to this personal growth and the transition to a new stage or level" (Kasatkina 2018, p. 15).
} 
and elucidates the esthetic function of artistic elements in its structure. A comparative analysis of Khomyakov's early lyrics shows how poetic ideas are refracted in his historical-philosophical discourse.

Tatiana Kasatkina concentrates on Dostoevsky's authorial theory of creative work and the writer's use of composite, double-layered images as a fundamental philosophy of personhood that opens a path toward personal transformation.

Sergei Kibalnik analyzes Dostoevsky's influence, especially as the author of The Brothers Karamazov, on Western psychoanalytic philosophy (e.g. Jacques Lacan and Slavoj Žižek), which reframes the Russian writer's ideas for its own interpretation of present-day reality.

Elizaveta Zakharova focuses on the late nineteenth-century literary critic Yuri Govorukha-Otrok's perception of Vladimir Solovyov's aesthetic theory through the prism of religious, philosophical, and issues relevant to understanding of national self-consciousness and national self-identity.

Olga Shalygina uses the theory of generated time flows and the theory of metabolic time, developed in the twentieth century by two Russian scientists, the astrophysicist Nikolay Kozyrev (1908-1983) and the biophysicist Alexandr Levich (1945-2016), to rethink such familiar literary and aesthetic categories as time, space, traditions, rhythm, and the psychology of creativity and perception, as well as to reflect on the laws of text generation and on the role of rhythm in Anton Chekhov's poetics and drama, specifically in his The Cherry Orchard.

Evgeny Ponomarev argues that Lev Shestov's philosophical text and Ivan Bunin's literary texts about Leo Tolstoy are the main point of convergence between the existentialist philosopher and the writer, and Bunin's essay "The Liberation of Tolstoy" should be interpreted in the light of Shestov's ideas.

Yulia Anokhina systematizes the cases when Vyacheslav Ivanov evokes Evgeny Boratynsky's poetry and explains the reasons of attribution the Symbolist poet and his Romantic predecessor to the tradition of "the poetry of thought." Her specific focus is on Ivanov's interest concerning the way Boratynsky's lyrics relate to his philosophy of art and how by appealing to Boratynsky's poetry Ivanov sought to express his own aesthetic credo.

The significance of the figure of Adam in the artistic philosophy of Acmeism is the main theme of Anton Filatov's paper, in which the author shows the differences among the Adamic myths embraced by such representatives of this literary school as Nikolay Gumilyov, Sergey Gorodetsky, and Osip Mandelstam.

Svetlana Seryogina analyzes the socio-political motifs in the early lyrical poems of Nikolai Klyuev. She examines them through Klyuev's assimilation of the philosophy of social Christianity and shows how the most important categories of HuguesFélicité Robert de Lamennais's pamphlet Modern Slavery (Lamennais 1840), brotherhood, cooperation, and self-sacrifice, are transformed in Klyuev's poetry into the ideas of co-working with God and spiritual co-crucifixion with Christ.

Elena Takho-Godi looks into the disputes between the well-known literary critic Yuly Aykhenvald and the Eurasianists, who wished to prove that Russia and the West were mutually alien entities. The author shows that Aykhenvald's historiosophical views are embodied in his literary-critical essays on Pushkin: the critic sees in 
the poet a model of spiritual and aesthetic balance and the embodiment of his own historiosophical aspirations for a harmonious fusion of Russia and the West.

Anastasia Gacheva explores the work of Nikolai Fedorov's followers, Cosmist philosophers of the 1920s-1930s, Aleksandr Gorsky, Nikolay Setnitsky, and Valeryan Muravyov. The connection between their aesthetics and creative practices is demonstrated. In their poetic and prose experiments are revealed syncretic genre forms (philosophical mystery play, philosophical poem, philosophical aphorism, etc.). The author analyses ideas of the projectivity of culture, history as a work of salvation, and art as a life-creating force.

Natalia Mikhalenko examines how, in the works of the Symbolist writer Dmitry Merezhkovsky and the economist-cum-utopian-writer Alexandr Chayanov, understanding of the culture and philosophy of Ancient Egypt and Babylon is linked to the search for historical harmony and a synthesis of worldviews that can overcome chaos, can unite and reconcile people.

Konstantin Zenkin looks at Aleksei Losev's literary texts in order to demonstrate the internal unity of Losev's music mythology (the view of music as a reflection of the self-consciousness of a person belonging to a certain historical-cultural epoch), as well as to uncover its evolution and continuity from his early musical and critical works of the 1920s to the artistic prose of the 1930s.

An excellent illustration of these theoretical arguments is a fragment from Losev's novel Zhenschina-Myslitel' (The Woman-Thinker, 1933) translated and with a brief introduction by Vladimir Marchenkov.

The subject of Oleg Korostelev's paper is the philosophical influences on the poetry of the Russian émigré authors during the 1920s-1930s. Korostelev argues for the decisive role of the literary critic Georgy Adamovich, whose philosophy of poetry at once inspired young poets and echoed the existential ideas of Lev Shestov. Unfortunately, the author, who made an invaluable contribution to the study of the Russian émigré culture, did not live to see the publication of this study.

Another great loss for study of the twentieth-century Russian culture was the recent death of Robert Bird, associate professor and chair of both the department of cinema and media studies and the department of Slavic languages and literatures at the University of Chicago. The reader will find an In Memoriam to him included in this issue. Professor Bird took a great interest in our group's project. In May 2018, he gave a talk "Towards the History of Positive Aesthetics" at a seminar organized by our research team, sharing with us the perspective of a contemporary Western literary scholar on the history of aesthetic ideas in Russia. According to him, the fact that Vladimir Solovyov called Nikolay Chernyshevsky's dissertation Esteticheskie otnosheniya iskusstva $k$ deystvitel'nosti (The aesthetic relations of art to reality, 1855) the "first step" toward positive aesthetics gives us a clue to understanding the main direction of Russian philosophical aesthetics toward connecting the realist and idealist trends. This tendency distinguishes it from the negative aesthetics that characterizes twentieth-century Western thought. The discussion that followed his talk once again showed how fruitful the cooperation of scholars from different countries and literary schools can be in studying complex methodological and interdisciplinary issues. 
Acknowledgements This research was conducted at the A.M. Gorky Institute of World Literature of the Russian Academy of Sciences with financial support from the Russian Science Foundation (RSF, Project No. 17-18-01432-П).

\section{References}

Azarova, N. M. (2010). Iazyk filosofii i iazyk poezii - dvizheniye navstrechu: (grammatika, leksika, tekst) [The language of philosophy and the language of poetry - movement toward rapprochement: Grammar, vocabulary, text]. Moscow: Gnosis.

Bourbon, B. (2004). Finding a replacement for the soul: Mind and meaning in literature and philosophy. Cambridge, London: Harvard University Press.

Bykova, M. F. (2011). Dostoevsky as the master of philosophical prose. Russian Studies in Philosophy, 50(3), 3-9.

Clark, T. (2008). Derrida, Heidegger, Blanchot: sources of Derrida's notion and practice of literature. Cambridge: Cambridge University Press.

Clowes, E. W. (2004). Fiction's overcoat: russian literary culture and the question of philosophy. Ithaca, London: Cornell University Press.

de Lamennais, F. R. (1840). De l'esclavage moderne. Bruxelles: Hauman.

Dobrokhotov, A. L. (2019). Vyacheslav Ivanov on Pushkin's The Gypsies: The antinomy of individualism and freedom. Russian Studies in Philosophy, 57(3), 260-269.

Feger, H. (Ed.). (2012). Handbuch Literatur und Philosophie. Berlin-Heidelberg: Springer.

Filosofiya i literatura: problemy vzaimnykh otnosheniy (materialy "Kruglogo stola") [Philosophy and literature: problems of mutual relations] (2009). Voprosy filosofii, 9, 56-96.

Gachev, G. D. (1981). Obraz v russkoi khudozhestvennoi kul'ture [The image in Russian artistic culture]. Moscow: Iskusstvo.

Gacheva, A. G. (2019). «Ideal ved' tozhe deystvitel'nost'...»: Russkaia filosofiia i literatura ["An ideal is also reality...": Russian philosophy and literature]. Moscow: Akademicheskii proiekt.

Grevtsova, E. S. (2011). On the "philosophical fate" of the work of Anton Chekhov. Russian Studies in Philosophy, 50(2), 83-98.

Halliburton, D. (1981). Poetic thinking: An approach to Heidegger. Chicago: University of Chicago.

Kantor, V. K. (2019). The establishment of Petrine-Pushkinian Russia: a philosophical perspective. Russian Studies in Philosophy, 57(3), 228-240.

Kasatkina, T. A. (2018). Filosofiya vospriyatiya literatury i iskusstva: o sub"yekt-sub"yektnom metode chteniya [Philosophy of perception of literature and art: On the subject-subject method of reading]. In: Takho-Godi, E.A. (Ed.) (2018a). Russkaia literatura i filosofia: Puti vzaimodeistvia, vypusk 1 [Series "Russian literature and philosophy: Ways of interaction", issue 1]. Moscow: Vodolei, pp. 14-50.

Kasatkina, T. A. (2019). Dostoevskii kak filosof i bogoslov: khudozhestvennii sposob vyskazyvaniia. Serya "Russkaia literatura i filosofia: Puti vzaimodeistvia", vypusk 4, redactor E. A. Takho-Godi [Dostoevsky as philosopher and theologian: an artistic way of speaking. Series "Russian literature and philosophy: Ways of interaction", issue 4, ed. by E. A. Takho-Godi]. Moscow: Vodolei.

Kibalnik, S. A. (2019). Khudozhestvennaia filosofiia A.S. Pushkina [A.S. Pushkin's artistic philosophy], 2nd ed. Saint-Petersburg: Petropolis.

Lamarque, P. (2009). The philosophy of literature. Malden, MA: Blackwell.

Mann, Yu.V. (1969). Russkaia filosofskaia estetika (1820-1830-e gody) [Russian philosophical aesthetics. (1820-1830s)]. Moscow: Iskusstvo.

Maymin, E.A. (1976). Russkaia filosofskaia poeziia. Poety-lyubomudry, A.S. Pushkin, F.I. Tiutchev [Russian philosophical poetry. The poets-liubomudry, A.S. Pushkin, F.I. Tiutchev]. Moscow: Nauka.

Nikolsky, S. A. (2016). Lermontov's Revolt: "I want to believe in good." Russian Studies in Philosophy, 54(2), 129-144.

Radionova, A. V. (2019). Liro-filosofskii metatekst v russkoi literature [Lyrical-philosophical metatext in Russian literature]. Smolensk: Izdatelstvo SmolGU.

Rudrum, D. (Ed.). (2006). Literature and philosophy: A guide to contemporary debates. London: Palgrave Macmillan. 
Rudrum, D., Askin, R., \& Beckman, F. (Eds.). (2019). New directions in philosophy and literature. Edinburgh: Edinburgh University Press.

Ryklin, M. K. (1992). Soznaniye i rech' v kontseptsii M.M. Bakhtina [Consciousness and speech in M.M. Bakhtin's conception]. In: M.M. Bakhtin kak filosof, pod redaktsiei L.A. Gogotishvili i P.S. Gurevich [M.M. Bakhtin as a philosopher, ed. by L.A. Gogotishvili and P.S. Gurevich]. Moscow: Nauka, pp. 175-189.

Schroeder, S. (Ed.). (2010). Philosophy of literature. Ratio special issues, December 2. Oxford: Wiley Blackwell.

Semenova, S.G. (2004). Metafizika russkoy literatury: V 2 t. [Metaphysics of Russian literature: In 2 vol.]. Moscow: Porog.

Sizemskaya, I. N. (Ed.). (2007). Poeziya kak zhanr russkoy filosofii : antologiia [Poetry as a genre of Russian philosophy: an antology]. Moscow: Institut filosofii RAN.

Sizemskaya, I. N. (2018). Russian nihilism in Ivan S. Turgenev's literary and philosophical investigations. Russian Studies in Philosophy, 50(3), 394-404.

Starobinski, J. (2014). Materiia idey (beseda s Sergeiem Zenkinym) [The material of ideas (conversation with Sergei Zenkin)]. Inostrannaya literature [Foreign literature], 2, 170-186.

Stellardi, G. (2004). Heidegger and Derrida on philosophy and metaphor: Imperfect thought. Amherst, NY: Humanity Books.

Takho-Godi, E.A. (2007). Khudozhestvennyi mir prozy A.F. Loseva [The artistic world of A.F. Losev's fiction]. Moscow: Bolshaia Rossiiskaia entziklopedia.

Takho-Godi, E. A. (2014). Aleksei Losev v epokhu russkoj revolutsii: 1917-1919 [Aleksei Losev in the era of the Russian revolution: 1917-1919]. Moscow: Modest Kolerov.

Takho-Godi, E. A. (Ed.). (2018a). Russkaia literatura i filosofia: Puti vzaimodeistvia, vypusk 1 [Series "Russian literature and philosophy: Ways of interaction", issue 1]. Moscow: Vodolei.

Takho-Godi, E. A. (Ed.). (2018b). Literatura i religiozno-filosofskaia mysl' kontsa XIX - pervoi treti XX veka. K 165-letiyu Vl. Solov'eva. Serya "Russkaia literatura i filosofia: Puti vzaimodeistvia”, vypusk 2 [Literature and religious-philosophical thought of the late $19^{\text {th }}-$ first third of the $20^{\text {th }}$ century. To the 165th anniversary of Vl. Solovyov. Series "Russian literature and philosophy: Ways of interaction", issue 2]. Moscow: Vodolei.

Takho-Godi, E. A. (Ed.). (2018c). Alexei F. Losev: On the occasion of his 125 Birth anniversary. Russian Studies in Philosophy, special issue, vol. 56, No 6.

Takho-Godi, E. A. (Ed.). (2019). Literatura i filosofia: Ot romantizma $k$ XX veku. K 150-letiiu so dnia smerti Vl. F. Odoevskogo. Serya "Russkaia literatura i filosofia: Puti vzaimodeistvia”; vypusk 3 [Literature and philosophy: From Romanticism to the 20th century. To the 150th anniversary of Vl. F. Odoyevsky's death. [Series "Russian literature and philosophy: Ways of interaction", issue 3]. Moscow: Vodolei.

Zhukova, O. A. (2019). The self-cognition of russian culture: Pushkin in the philosophical experience of Semyon Frank. Russian Studies in Philosophy, 57(3), 281-295.

Publisher's Note Springer Nature remains neutral with regard to jurisdictional claims in published maps and institutional affiliations. 